\title{
Assessment of macroalgal nitrogen limitation in a seasonal upwelling region
}

\author{
Rodney M. Fujita*, Patricia A. Wheeler**, Robert L. Edwards \\ College of Oceanography, Oregon State University, Corvallis, Oregon 97331, USA
}

\begin{abstract}
The relationship between nitrogen (N) availability and the growth of macroalgae in a seasonal upwelling region (Yaquina Head, Oregon, USA) was investigated. Water column nutrient concentrations were relatively high and stable during the winter, decreased in early spring, and were highly variable in the summer and early fall. Periods of high nutrient availability due to upwelling commenced in May and alternated with periods of low nutrient availability until September. Dissolved inorganic nitrogen (DIN) concentration was a poor predictor of $N$ limitation of macroalgal growth due to the ability of macroalgae to store $\mathrm{N}$ for continued growth when ambient DIN concentrations were low. The relationship between growth and internal $\mathrm{N}$ content for Pelvetiopsis limitata (Phaeophyta : Fucaceae) and Ulva rigida (Chlorophyta:Ulvales) depended on the $\mathrm{N}$ source and culture conditions. Results of an in situ $N$ enrichment experiment indicated that $P$. limitata growth may have been $N$ limited in April and May. A nitrogen budget for $P$. limitata indicated that $\mathrm{NH}_{4}^{+}$was the major $\mathrm{N}$ source for growth at Yaquina Head, due to its rapid uptake, despite the greater abundance of $\mathrm{NO}_{3}^{-}$The critical $\mathrm{N}$ value (tissue $\mathrm{N}$ level during the transition from $\mathrm{N}$ limiting to non- $\mathrm{N}$ limiting conditions) for growth of $U$. rigida on $\mathrm{NO}_{3}^{-}\left(\leq 2.4 \%\right.$ dry wt) was much lower than that for growth on $\mathrm{NH}_{4}^{+}(3.0 \%$ dry wt). Ammonium was the major $\mathrm{N}$ source for growth of $U$. rigida at Yaquina Head, and growth was probably $\mathrm{N}$-limited in April and May, as indicated by the critical $\mathrm{N}$ level for growth on $\mathrm{NH}_{4}^{+}$Growth of U. rigida may also have been intermittently $\mathrm{N}$-limited between upwelling events. Problems with the use of cirtical $\mathrm{N}$ levels and nutrient monitoring to assess $\mathrm{N}$ limitation are discussed. Use of critical tissue $\mathrm{N}$ levels is complicated by variations in this parameter with the $\mathrm{N}$ source used for growth.
\end{abstract}

\section{INTRODUCTION}

The seasonality of macroalgal productivity is often controlled by light and nutrient availability. In temperate regions, irradiance and growth are usually low during the winter and early spring, while nutrient levels are high (e.g. Gagne et al. 1982). As light conditions improve, nutrients are utilized by both macroalgae and phytoplankton and often become depleted in the euphotic zone. Low nutrient levels may limit primary production during the summer and fall when adequate light is still available.

Most studies of the relationship between the availability of dissolved inorganic nitrogen (DIN) and macroalgal productivity have been carried out in Atlantic coastal waters (e.g. Chapman \& Craigie 1977, Hanisak 1979, Harlin \& Thorne-Miller 1981, Davison et al. 1984)

\footnotetext{
- Present address: Environmental Defense Fund, 257 Park Avenue South, New York, New York 10010, USA

- Corresponding author
}

where winter mixing provides the dominant seasonal input of DIN to the euphotic zone. A contrasting situation occurs along the eastern boundaries of the oceans where coastal upwelling occurs. Upwelling is particularly strong off the coast of Oregon and the upwelling season usually spans 6 mo (May to October). During this period upwelling is episodic, with 4 to 6 major upwelling events and the same number of weaker events (Small \& Menzies 1981).

Other natural environments (such as salt ponds and estuaries) and cultivation systems also have periodic episodes of high DIN availability ('pulses') superimposed on a background of low DIN availability. In these environments, macroalgae take up DIN rapidly when available and store it to support growth between pulses (Rosenberg \& Ramus 1982, Rosenberg et al. 1984, Fujita 1985a, Lapointe 1985). Gerard (1982) has suggested that the giant kelp Macrocystis pyrifera is able to use transient pulses of $\mathrm{NO}_{3}^{-}$supplied by upwelling, thermocline excursions (Zimmerman \& Kremer 1984), and runoff to alleviate $N$ starvation in southern Califor- 
nia waters. However, some species have a limited capacity to store $\mathrm{N}$ perhaps due to their high growth rates (Fujita 1985a). Thus, the frequency with which DIN pulses occur in the environment may determine whether or not a particular species is N-limited. For example, growth of the red alga Gracilaria tikvahiae continued unabated in a salt pond when enriched with DIN only once every $5 \mathrm{~d}$, while abundance of the fastgrowing green algae Ulva lactuca and Enteromorpha spp. greatly decreased (Fujita 1985b). Nutrient storage uncouples growth from nutrient availability, complicating the assessment of nutrient limitation. To determine and predict the effects of nutrient availability on macroalgal growth in the field, it is necessary to measure nutrient concentrations on an ecologically relevant scale, assess the kinetics of nutrient uptake, determine which nutrient species are being utilized, and measure the length of time that growth can be supported in the absence of nutrients (i.e. the nutrient storage capacity).

The relationship between internal nutrient levels and growth rates has been analysed extensively for both higher plants and for phytoplankton. For microalgae, a well-defined hyperbolic relationship between cell nutrient content and growth rate is found in continuous cultures (Droop 1974). The relationship for mineral content of plant tissue, on the other hand, is more complex and is divided into three or more 'zones' of nutrient status (Smith 1962), with the 'critical level' usually being defined as the level separating the zone of deficiency and the zone of adequacy (Ulrich 1952). Here, we follow Hanisak's (1979) definition of the 'critical nutrient' content as the internal concentration that just limits maximal growth for macroalgae.

In this paper, we describe the temporal variability of nutrients in an intertidal macroalgal community at Yaquina Head (Oregon, USA) over a seasonal cycle. We determined critical tissue $N$ levels by growing macroalgae in continuous culture systems with varying levels of $N$ supply, then used these values to predict the onset of $\mathrm{N}$ limitation in situ. We also report 'subsistence' levels, tissue nutrient levels at zero growth rate, as used in the phytoplankton literature (Eppley \& Strickland 1968), and conducted an in situ $N$ enrichment experiment to evaluate $\mathrm{N}$ limitation.

\section{MATERIALS AND METHODS}

Site description. Water samples and algal specimens were collected from Yaquina Head, Oregon, USA $\left(44^{\circ} 41^{\prime} \mathrm{N}, 124^{\circ} 05^{\prime} \mathrm{W}\right)$. Yaquina Head is a rocky headland extending about $2 \mathrm{~km}$ into the Pacific Ocean. The field experiment was conducted on a relativly flat rock platform in the midst of a dense bed of Pelvetiopsis limitata (Gardn.) (Phaeophyta Fucaceae) at the south end of Yaquina Head. P. limitata, with Fucus distichus (L.) (Powell) (Phaeophyta: Fucaceae), dominates the high intertidal zone and is present year-round. All $P$. limitata thalli were collected from the vicinity of this site. Ulva rigida C. Ag. (Chlorophyta: Ulvales) was present lower in the intertidal at the same site, and abundance was highly variable, but was generally greater during the summer than during spring and fall. $U$. rigida was scarce during the winter. U. rigida thalli were collected from the vicinity of the field experiment and nutrient monitoring site for tissue $\mathrm{N}$ analysis; thalli for growth experiments were collected in nearby Yaquina Bay, where they were present in much greater abundance. Other Ulva species also occurred at Yaquina Head, but were not as abundant.

Nutrient concentrations and tissue $\mathrm{N}$ content at the field site. We collected water samples from Yaquina Head in polypropylene bottles over various temporal scales. In August 1985, we sampled surface water hourly for $24 \mathrm{~h}$ to characterize tidal variations in nutrient concentrations during an upwelling event. For high-tide samples, we used a garden hose fitted with a perforated bottle to minimize intake of debris. For low tide samples debris was not evident. Water samples were taken $6 \mathrm{~m}$ seaward from the edge of the rock ledge at a depth of ca $1 \mathrm{~m}$ below the surface through hosing connected to a hand-held bilge pump. All samples were packed in ice and filtered through Whatman $\mathrm{GF} / \mathrm{C}$ glass-fiber filters within $4 \mathrm{~h}$ of collection. They were analysed for $\mathrm{NH}_{4}^{+}, \mathrm{NO}_{3}^{-}, \mathrm{NO}_{2}^{-}$, and $\mathrm{PO}_{4}^{3-}$ within $6 \mathrm{~h}$ of collection on a Technicon Autoanalyzer II using the methods of Grasshoff et al. (1983) with minor modifications. Nitrite concentrations were always less than $5 \%$ of $\mathrm{NO}_{3}^{-}$concentrations and are not reported here. Coefficients of variation for replicates in each nutrient analysis were typically $<1 \%$.

We sampled water in the same manner at both high and low tides every 1 to $3 \mathrm{~d}$ during June, July and August. Samples were taken throughout the rest of the year at intervals of 1 to $30 \mathrm{~d}$, usually at or near low tide. These samples were filtered and frozen within $1 \mathrm{~h}$ of collection and stored for later analysis. The differences in nutrient concentrations observed between fresh and frozen samples were small for $\mathrm{NO}_{3}^{-}(1.7 \%$ greater in fresh samples) but rather high for $\mathrm{NH}_{4}^{+}$and $\mathrm{PO}_{4}^{3--}(10.3$ and $10.5 \%$ greater in fresh samples, respectively).

We collected whole specimens of Pelvetiopsis limitata and Ulva rigida periodically from the general vicinity of our experimental site, taking care not to damage the thalli. Debris was removed by hand and the thalli rinsed in nutrient-free seawater (see 'Critical $N$ content'). Excess water was removed by shaking or spinning in a salad spinner for $15 \mathrm{~s}$. The thalli were frozen at $-70^{\circ} \mathrm{C}$ for at least $2 \mathrm{~h}$, freeze-dried for at least $24 \mathrm{~h}$, and ground to a fine powder in a Spex Industries 
mixermill. Carbon and $\mathrm{N}$ contents were measured with a Perkin-Elmer $240 \mathrm{~B}$ elemental analyzer. For some samples, $\mathrm{N}$ content was measured as $\mathrm{NO}_{3}^{-}$after persulfate digestion (Grasshoff et al, 1983), which gave results comparable to those obtained using the elemental analyzer.

Outdoor culture experiments. Pelvetiopsis limitata and Ulva rigida were grown in outdoor flow-through tanks at a density of $10 \mathrm{~g}$ wet wt per tank $\left(0.9 \mathrm{~g} \mathrm{l}^{-1}\right)$. The outdoor culture system was developed to provide high turnover rates to simulate natural conditions more closely than was possible using an indoor culture system. The tanks were injection-molded ABS plastic halfcylinders $30 \mathrm{~cm}$ in diameter and $43 \mathrm{~cm}$ in length, arranged in sets of 4 . Outflow pipes were fitted with perforated plastic bottles to prevent clogging, resulting in a working volume of $11.5 \mathrm{l}$. Agitation was provided with compressed air; nylon needle valves were used to equalize flow rates. Plexiglas covers kept out rain and debris. Biomass was cropped weekly to $10 \mathrm{~g}$ and growth rate $\left(\% \mathrm{~d}^{-1}\right)$ was calculated as In $\left(W_{t} W_{\mathrm{o}}^{-1}\right) t^{-1} \times 100$, where $W_{\mathrm{t}}$ is the wet weight at the end of the growth period, $W_{0}$ is the weight at the start of the growth period, and $t$ is the duration of the period. $P$. limitata was cultured from 20 April to 20 May 1986 to coincide with the in situ enrichment experiment. $U$. rigida was cultured from 5 August to 27 August 1986.

Salinity-adjusted (30 to $32 \%$ ) seawater from Yaquina Bay was sand-filtered and pumped through 10 - and 1 um cartridge filters into a 4 -tiered, air-agitated, flowthrough nutrient stripping tank stocked with Ulva and Enteromorpha spp. Flow rates were adjusted to maximize the residence time of the water and thus increase the efficiency of nutrient removal. The water was then pumped to a $600 \mathrm{l}$ head tank provided with an overflow to maintain a constant head, and directed through a carefully leveled manifold to the tanks. Each tank was provided with a nylon needle valve for control of flow rates.

Two 20001 reservoir tanks were filled with nutrientstripped water every 3 to $4 \mathrm{~d}$ and enriched to $150 \mu \mathrm{M}$ $\mathrm{NH}_{4}^{+}$or $\mathrm{NO}_{3}^{-}$. Phosphate $(15 \mu M)$ was provided in each case to prevent $\mathrm{P}$ limitation $(\mathrm{N}: \mathrm{P}=10: 1)$. The enriched seawater was then pumped to separate $600 \mathrm{l}$ head tanks with overflows and allowed to flow into the tanks through nylon needle valves. The $2000 \mathrm{l}$ reservoir tanks were operated in tandem with two $600 \mathrm{l}$ tanks to provide nutrient-enriched water continuously.

Nominal influent $N$ concentrations of $0,10,20,30,40$, and $50 \mu M$ were achieved by adjusting the relative flow rates of enriched and unenriched seawater. The total flow rate to each tank was held constant at $216 \mathrm{l} \mathrm{d}^{-1}$ (18.8 turnovers $\mathrm{d}^{-1}$ ). The flow rates were checked daily and adjusted as necessary. The treatments were assigned to tanks randomly to avoid systematic effects of shading or other gradients in the outdoor courtyard where the system was located. Inorganic $\mathrm{N}$ and $\mathrm{P}$ concentrations in the seawater prior to nutrient enrichment were always less than 3.4 and $0.41 \mu M$, respectively. Dissolved organic N (DON) and $P$ were not measured. The possible presence of DON may have contributed to the fast growth of Ulva rigida in outdoor cultures, but the use of DON by Pelvetiopsis limitata is not likely (see 'Discussion'). Salinity ranged between 30 and $32 \%$, while temperature $\left(11\right.$ to $\left.20^{\circ} \mathrm{C}\right)$ and irradiance were highly variable.

Indoor culture experiments. The critical $\mathrm{N}$ content was determined by measuring tissue $N$ content for algae grown over a range of growth rates controlled by nitrogen supply. We grew Pelvetiopsis limitata from 23 October to 23 December 1986 in 1.2 l plastic containers with water input and output fittings and filtered air agitation. Small, non-reproductive thalli $(2$ to $3 \mathrm{~cm}$ in length) with intact holdfasts were collected from the field site and cultured in enriched seawater in a constant temperature room. The seawater was obtained from Yaquina Bay and mixed with high salinity seawater as needed to maintain salinity above $30 \%$. Nutrients were stripped from the water in 20001 outdoor tanks by dense, air-agitated batch cultures of Ulva spp. for at least $4 \mathrm{~d}$. The water was then pumped through 10 - and 1 - $\mu \mathrm{m}$ cartridge filters, and a Millipore Pellicon ${ }^{(B)}$ high-volume tangential flow filter system was used to remove $>0.2 \mu \mathrm{m}$ particulate material. Residual concentrations of dissolved inorganic $\mathrm{N}$ and $\mathrm{P}$ were always less than 1.9 and $0.15 \mu M$, respectively.

Separate polypropylene carboys were filled with seawater enriched with $\mathrm{f} / 2$ vitamins and minerals (Guillard 1975) and varying amounts of $\mathrm{NH}_{4}^{+}$or $\mathrm{NO}_{3}^{-}$plus sufficient $\mathrm{PO}_{4}^{3-}$ to ensure $\mathrm{N}$ limitation (N:P $=2: 1$ ). Medium was pumped to the cultures at $1 \pm 0.1 \mathrm{ml} \mathrm{min}^{-1}(0.5 \mathrm{l}$ $\mathrm{d}^{-1}$ ), light was maintained at $370 \mu \mathrm{E} \mathrm{m}^{-2} \mathrm{~s}^{-1}$ (measured in culture medium) with cool white GE fluorescent tubes, and temperature was held constant at $13^{\circ} \mathrm{C}$. Photosynthesis should have been saturated at the light intensity used (Oakes \& Murray 1983). However, we found in preliminary studies that Pelvetiopsis limitata became necrotic and died after about $1 \mathrm{wk}$ of constant submergence under these conditions. We subsequently simulated natural conditions in the high intertidal by providing a 14:10 L:D cycle (lights on between 07:00 and 21:00 h), with 8 h of submergence in the light, $6 \mathrm{~h}$ of emersion in the light, and $10 \mathrm{~h}$ of emersion in the dark. Thalli were simply removed from the medium and left in plastic weighing dishes for the emersion period. Natural populations of $P$. limitata experienced a similar cycle of photoperiod and submergence/emergence at Yaquina Head during the spring

Five to 7 thalli of ca $1.5 \mathrm{~g}$ wet wt each were cultured in each container, resulting in 7.5 to $8.5 \mathrm{~g}$ wet wt total 
biomass and a biomass:volume ratio of about $8 \mathrm{~g}^{-1}$. Growth was measured weekly immediately after removal from the medium at 17:00 $\mathrm{h}$ by spinning in a salad spinner for $15 \mathrm{~s}$ and weighing. We found that this resulted in consistent weights after repeated periods of submergence. No systematic effects of desiccation during weighing (about $1 \mathrm{~h}$ ) were observed. Tissue was cropped at each weighing to maintain the biomass at about $8 \mathrm{~g}$. Growth rate $\left(\% \mathrm{~d}^{-1}\right)$ was calculated as $\ln \left(W_{t} W_{0}^{-1}\right) t^{-t} \times 100$, where $t$ is the number of days between weighings, $W_{0}$ is the initial weight, and $W_{t}$ is the final weight. The cropped tissue was frozen at $-70^{\circ} \mathrm{C}$ and freeze-dried in preparation for CHN analysis.

Ulva rigida was grown from 16 September to 20 October 1986 under the same conditions of irradiance, temperature, and nutrient loading. Photoperiod was set at 13:11 (L:D) and the algae were continuously submerged. Biomass was cropped to $6.5-8.5 \mathrm{~g}$ wet wt weekly at every weighing. Growth rate was calculated as described above.

In situ nutrient enrichment. Naturally occurring clumps of Pelvetiopsis limitata attached to barnacles were removed from the field site and attached to $10 \times$ $20 \times 1 \mathrm{~cm}$ black, UV-resistant plastic plates with Marine-Tex marine epoxy cement. Cement was applied between the barnacles and plates and allowed to cure for $24 \mathrm{~h}$. Plates were inverted over a tank with flowing seawater to keep the thalli submerged while the cement dried. Initial weights were determined after the algae were allowed to dry for $4.5 \mathrm{~h}$ at $20^{\circ} \mathrm{C}$. We attached the plates directly to black basalt at the field site with stainless steel bolts and expansion nuts. The treatments were distributed randomly over a level platform in the midst of a dense bed of $P$. limitata at Yaquina Head.

Daily at lowest low tides (Oregon's semidiurnal tides are asymmetrical) between 25 April and 13 May 1986 we enriched the algae by unbolting the plates and placing them in translucent buckets filled with $7 \mathrm{l}$ of freshly collected seawater for at least $2 \mathrm{~h}$. We enriched

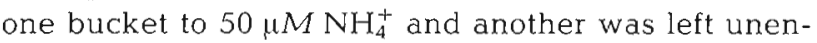
riched to serve as a control. The buckets were swirled every 10 to $15 \mathrm{~min}$ to reduce diffusion resistance. Enrichment was continued for $18 \mathrm{~d}$; at the end of the experiment the plates were collected and allowed to dry in the laboratory for $4.5 \mathrm{~h}$ at $20^{\circ} \mathrm{C}$ before the final weighing. Growth was calculated as the difference between the initial and final weights. Attempts to conduct this experiment with Ulva rigida failed due to excessive tissue loss.

In situ growth rates. We measured the growth rates of Pelvetiopsis limitata thalli which were cemented onto nylon bolts that were threaded into plastic plates attached to the rock during March and early April of
1986. We found that the product of the longest frond length and the number of fronds was linearly related to wet weight $\left(r^{2}=0.9\right)$. Therefore, weight gain could be extrapolated from frond length. We measured frond lengths and numbers weekly during the experimental period. We also established a permanent transect line with markers adjacent to individual thalli. Frond length and number of thalli along the transect were measured weekly as an independant estimate of growth rate under undisturbed conditions.

\section{RESULTS}

\section{Nutrient concentrations and tissue $\mathrm{N}$ content at the field site}

We characterized the temporal distribution of macronutrients at Yaquina Head on time scales ranging from hours to months. Hourly sampling, over a tidal cycle in August (during upwelling) revealed that $\mathrm{NO}_{3}^{-}$ concentrations ranged between 15 and $22 \mu M$ with highest concentrations generally occurring at high tides (Fig. 1). Ammonium and $\mathrm{PO}_{4}^{3-}$ concentrations were low ( $<1$ and $3 \mu M$, respectively) and did not vary significantly over the tidal cycle (Fig. 1). For sampling dates between mid-June and mid-August, low-tide $\mathrm{NO}_{3}^{-}$concentrations were an average of $72 \%$ of hightide concentrations

Upwelling events were detected and characterized by sampling every 2 to $4 \mathrm{~d}$ without regard to the tidal cycle (Fig. 2). Upwelling commenced in mid-May 1985 and resulted in pulses of elevated nutrient concentrations (henceforth to be called pulses) ( 7 to $28 \mu \mathrm{MNO}_{3}^{-}$and 1 to

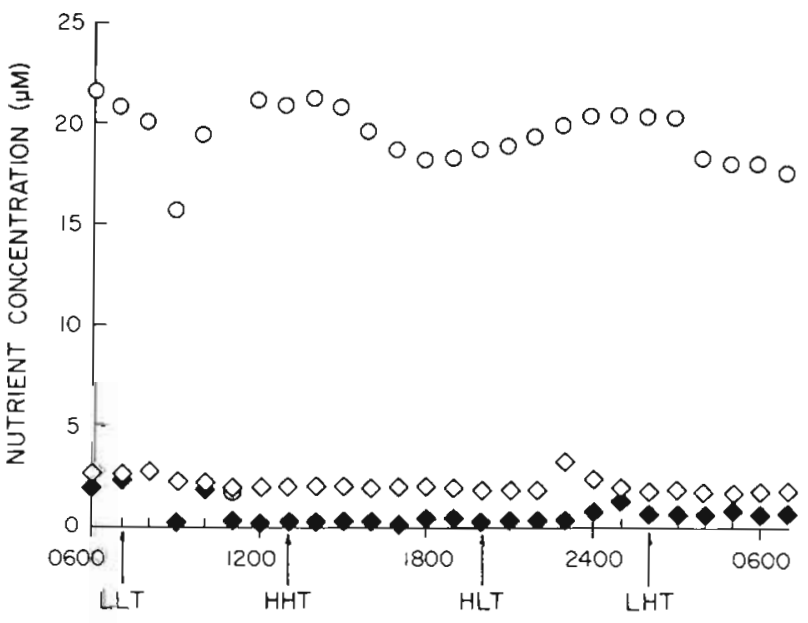

Fig. 1. Tidal cycle of nutrient abundance in surface water 10 to $3 \mathrm{~m}$ depth) at Yaquina Head, 29 to 30 Aug 1985. Nitrate (b), $\mathrm{PO}_{4}^{3-}(0)$, and $\mathrm{NH}_{4}^{+}(\uparrow)$ concentrations are shown. LLT: lowest low tide; HHT highest high tide; HLT: highest low tide; LHT lowest high tide 


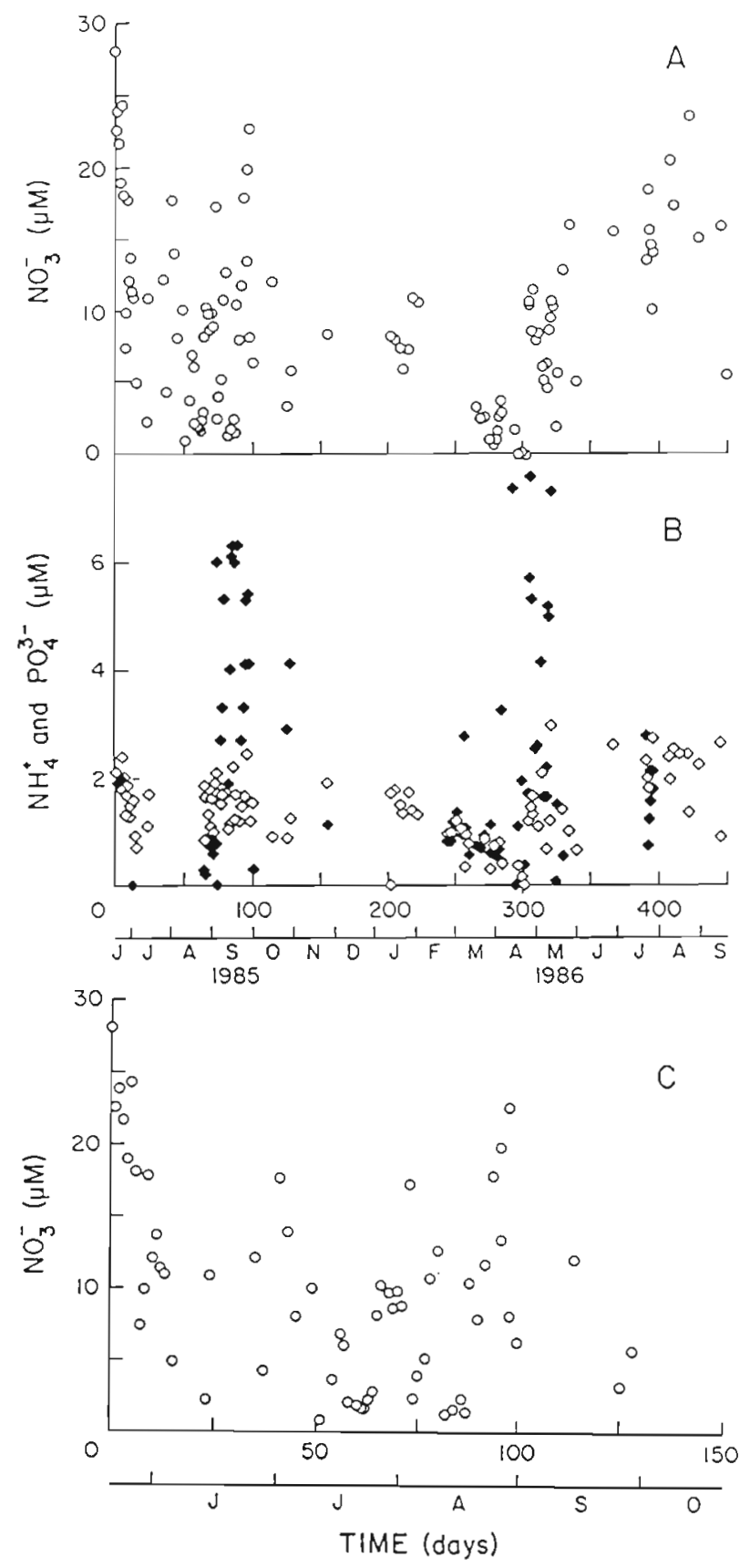

Fig. 2. (A) Seasonal cycle of $\mathrm{NO}_{3}^{-}$concentration and (B) $\mathrm{NH}_{4}^{+}$ $(\bullet)$ and $\mathrm{PO}_{4}^{3-}(\diamond)$ concentration at Yaquina Head. Note the scale change. (C) Nitrate concentration during the upwelling season, 1985

$3 \mu \mathrm{MPO}_{4}^{3-}$ ) separated by periods of low nutrient availability during July and August $\left(0.7\right.$ to $3 \mu \mathrm{MNO}_{3}^{-}$and 1 to 1.3 $\mu \mathrm{MPO}_{4}^{3-}$ ) (Fig. 2B, C). In June 1986, $\mathrm{NO}_{3}^{-}$concentrations were usually above $7 \mu \mathrm{M}$. Ammonium concentrations ranged between 0 and $8 \mu M$ (Fig. 2B); these unusually high levels may have been due to the large deposits of guano in the area. In September and
October, high nutrient concentrations occurred sporadically, ranging from 1.3 to $10.5 \mu \mathrm{MNO}_{3}^{-}, 0.9$ to $2.2 \mu \mathrm{M}$ $\mathrm{PO}_{4}^{3-}$, and 0 to $6.3 \mu \mathrm{M} \mathrm{NH}_{4}^{+}$. Satellite and ship-based thermal analysis indicated that the 1985 upwelling season ceased abruptly during the last few days of September (NOAA 1985); the moderately high $\mathrm{NO}_{3}^{-}$ concentrations observed during October were therefore probably residual (Fig. 2A). Nutrient concentrations were more stable during the winter ( 6 to $12 \mu \mathrm{MNO}_{3}^{-}$and 1 to $2 \mu \mathrm{MPO}_{4}^{3-}$ ) and decreased in March to 0 to $4 \mu \mathrm{M}$ $\mathrm{NO}_{3}^{-}$and 0.2 to $1 \mu \mathrm{MPO}_{4}^{3-}$. The decrease in nutrients may have resulted from a spring phytoplankton and macroalgal bloom (Stefánsson \& Richards 1964). In 1987, nutrient levels were also relatively low during March and early April (0.8 to $5.7 \mu \mathrm{MNO}_{3}^{-}$and 0.6 to 1.9 $\mu \mathrm{MNH}_{4}^{+}$), increasing in late April (15 to $23 \mu \mathrm{MNO}_{3}^{-}$and 1.9 to $4.4 \mu M \mathrm{NH}_{4}^{+}$(data not shown).

\section{Tissue $\mathbf{N}$ content of naturally occurring algae}

Tissue N level of Pelvetiopsis limitata thalli collected from Yaquina Head ranged from 1.5 to $2.2 \%$ dry wt but showed no significant seasonal variation (Fig. 3). The tissue $N$ content of Ulva rigida thalli collected from Yaquina Head was more variable ( 2.1 to $4.2 \%$ dry wt), but also showed no distinct seasonal trend (Fig. 3).

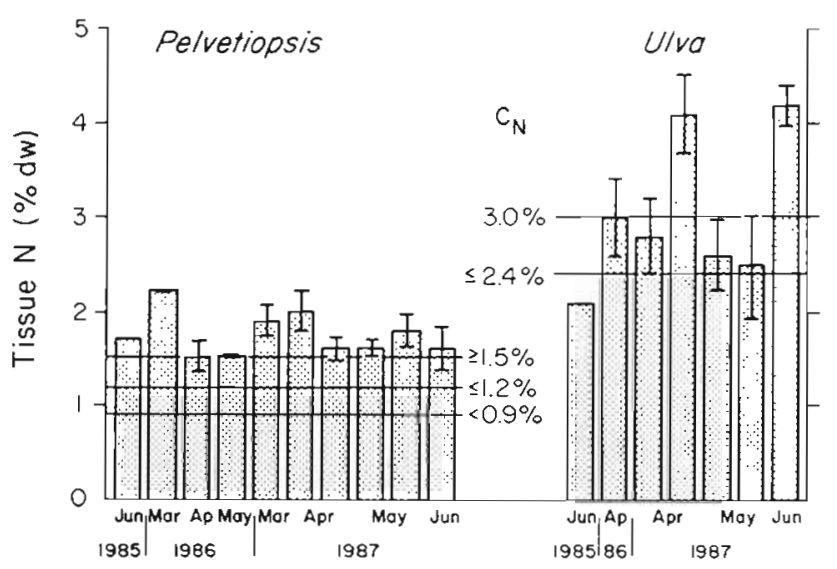

Fig. 3. Pelvetiopsis limitata and Ulva rigida. Tissue $\mathrm{N}$ content of specimens collected at Yaquina Head. Two collections were made for each of April and May 1987. Error bars indicate 1 standard deviation. $\mathrm{C}_{\mathrm{N}}$ (and horizontal lines) $=$ critical $\mathrm{N}$ level (see text)

\section{Growth kinetics}

Growth of Pelvetiopsis limitata was hyperbolically related to influent $\mathrm{NH}_{4}^{+}$loading (concentration $\times$ culture turnover rate) and was a linear function of influent $\mathrm{NO}_{3}^{-}$loading in outdoor culture after 10 to $17 \mathrm{~d}$ 
of acclimation (Fig. 4A). Growth was faster when $\mathrm{NH}_{4}^{+}$ was the N source. Growth at nominally zero N loadings probably resulted from residual inorganic $N(\leq 3.3 \mu M)$ in the incoming medium which is equivalent to a loading of $\leq 0.7 \mathrm{mmol} \mathrm{d}^{-1}$. In indoor culture growth was a hyperbolic function of $\mathrm{NH}_{4}^{+}$and $\mathrm{NO}_{3}^{-}$loading after 64 and $54 \mathrm{~d}$ of acclimation, respectively, but growth rates were much lower than for outdoor culture (Fig. 4B).

Growth of Ulva rigida in outdoor culture after $10 \mathrm{~d}$ of acclimation was independent of $\mathrm{NH}_{4}^{+}$loading at low levels and of $\mathrm{NO}_{3}^{-}$loadings at high levels. At higher $\mathrm{NH}_{4}^{+}$loading and lower $\mathrm{NO}_{3}^{-}$loading, growth rates were positively correlated with $\mathrm{N}$ loading (Fig. 4C). Growth at nominally zero $\mathrm{N}$ loading probably resulted from residual inorganic $N$ in the incoming medium as noted above for Pelvetiopsis limitata. U. rigida growth in indoor culture was a linear function of $\mathrm{NO}_{3}^{-}$loading, but showed a weaker positive correlation with $\mathrm{NH}_{4}^{+}$ loading after a $19 \mathrm{~d}$ acclimation period (Fig. 4D).

\section{Critical N content}

Growth rates of Pelvetiopsis limitata were relatively high and constant at tissue $\mathrm{N}$ levels between 0.9 and $2.2 \%$ dry wt for algae grown outdoors on $\mathrm{NH}_{4}^{+}$(Fig. $5 \mathrm{~A})$. For algae grown outcloors on $\mathrm{NO}_{3}^{-}$, growth rate was nearly a linear function of tissue $N$. For algae grown indoors, growth rate was slow and independent of tissue $\mathrm{N}$ for $\mathrm{NH}_{4}^{+}$and linearly related to tissue $\mathrm{N}$ for
$\mathrm{NO}_{3}^{-}$(Fig. 5A). No single critical $\mathrm{N}$ value can be determined for $P$. limitata; the relationship between growth and tissue $\mathrm{N}$ content depends on $\mathrm{N}$ source and culture conditions such as irradiance, temperature, and culture turnover rate. All of these factors differed between the indoor and outdoor culture experiments. The critical $N$ value for growth indoors on $\mathrm{NO}_{3}^{-}$was $\geq 1.2 \%$ dry wt, but no value could be determined for growth on $\mathrm{NH}_{4}^{+}$. Critical $\mathrm{N}$ values for growth on $\mathrm{NH}_{4}^{+}$and $\mathrm{NO}_{3}^{-}$were $<0.9$ and $\geq 1.5 \%$ dry $w t$, respectively. Subsistence tissue $\mathrm{N}$ level (the level at which no growth occurs) was ca $0.5 \%$ dry wt.

The relationship between Ulva rigida growth and tissue $\mathrm{N}$ also appears to vary with $\mathrm{N}$ source and culture conditions (Fig. 5B). Thalli grown outdoors on $\mathrm{NH}_{4}^{+}$ exhibited $\mathrm{N}$ limitation at tissue $\mathrm{N}$ levels less than $3.0 \%$ dry wt, while outdoor growth on $\mathrm{NO}_{3}^{-}$resulted in a critical $\mathrm{N}$ level $\leq 2.4 \%$ dry wt. Indoor culture results did not yield critical $N$ levels because growth did not saturate at the tissue $\mathrm{N}$ contents achieved (Fig. 5B). Growth rates of $U$. rigida at the lowest $N$ loadings attainable in the indoor cultures indicate that the subsistence $\mathrm{N}$ level is ca $1.2 \%$ dry wt (Fig. 5B).

\section{In situ growth rates and effects of nutrient enrichment}

Growth rates of Pelvetiopsis limitata determined by outplanting $\left(3.7 \pm 1.5 \% \mathrm{~d}^{-1}\right)$ and transect methods $\left(3.9 \pm 3.6 \% \mathrm{~d}^{-1}\right)$ had high variance but agreed well
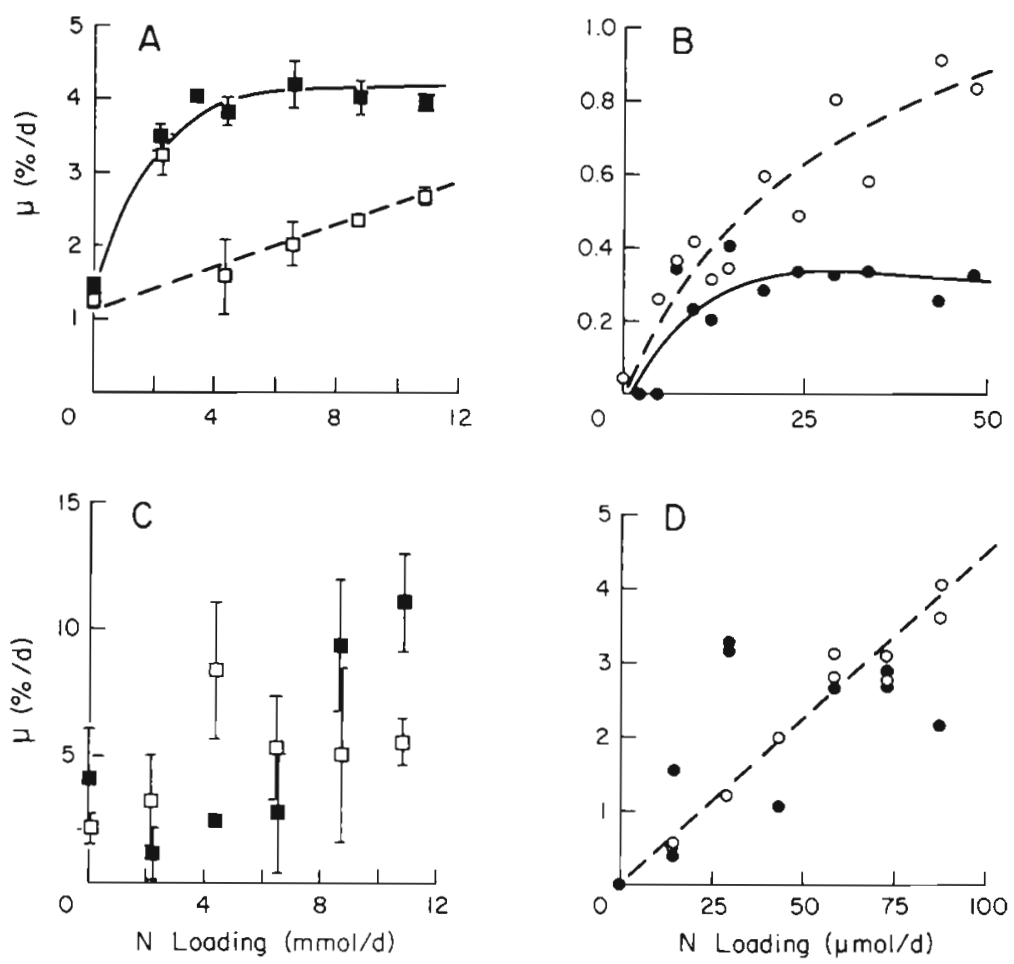

Fig. 4. Pelvetiopsis limitata and Ulva rigida. Mean growth rates on $\mathrm{NH}_{4}^{+}(\bullet \bullet)$ and $\mathrm{NO}_{3}^{-}(0, \square)$ plotted as functions of influent $\mathrm{N}$ loading for flow-through cultures. Error bars for outdoor cultures indicate 1 standard deviation. No replicates were run for indoor cultures. (A) $P$. limitata, outdoor culture. (B) P. Limitata, indoor culture. Note scale change. (C) U. rigida, outdoor culture. (D) U. rigida, indoor culture. Note scale changes 


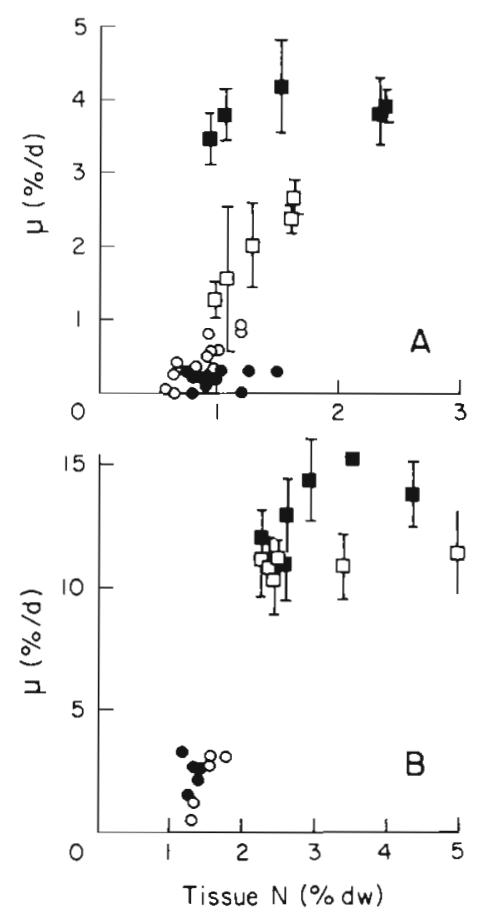

Fig. 5. Pelvetiopsis limitata and Ulva rigida. Relationship between growth rate and tissue $\mathrm{N}$ content for the indoor culture on $\mathrm{NO}_{3}^{-}(0)$ and $\mathrm{NH}_{4}^{+}(\bullet)$ and outdoor culture on $\mathrm{NO}_{3}^{-}$ () and $\mathrm{NH}_{4}^{+}(\mathbf{\square})$. Error bars indicate 1 standard deviation. No replicates were run for indoor cultures. (A) $P$. limitata. (B) U. rigida

Table 1. Pelvetiopsis limitata. In situ nitrogen enrichment. Experiment conducted at Yaquina Head from 25 April to 11 May 1986. Means \pm 1 standard deviation are presented

\begin{tabular}{|lccc|}
\cline { 2 - 4 } Treatment & $\begin{array}{c}\text { Number of } \\
\text { replicates }\end{array}$ & $\begin{array}{c}\text { Weight loss } \\
\text { (g wet wt) }\end{array}$ & $\begin{array}{c}\text { N content } \\
\text { (\% dry wt) }\end{array}$ \\
\hline Control & 3 & $1.8 \pm 0.26$ & $1.5 \pm 0.02$ \\
N-enriched & 3 & $0.11 \pm 0.15$ & $1.9 \pm 0.10$ \\
$\left(50 \mu \mathrm{MH}_{4}^{+}\right)$ & & & \\
\hline
\end{tabular}

with each other and with maximum growth rates observed in culture $\left(3.9 \pm 0.44 \% \mathrm{~d}^{-1}\right)$.

Pelvetiopsis limitata in both the control and the $\mathrm{N}$ enriched treatments showed a decrease in weight over the experimental period (Table 1). Since few grazers were observed on the $P$. limitata beds adjacent to the experimental site, and since no obvious grazer-induced damage was observed, we suggest that the weight loss was due to the senescence of individual fronds with subsequent breakage and loss. We observed senescent fronds and frequent signs of breakage within both naturally occurring and outplanted clumps of thalli. Similar numbers of thalli were lost from control and $N$ enriched treatments (5 and 6, respectively; the treat- ments initially had 17 and 13 thalli, respectively). Since biomass loss was relatively uniform between the treatments, a comparison of growth rates (with less loss indicating more rapid growth) can be made. Algae enriched with $N$ lost significantly $(p<0.05$, MannWhitney $U$-test) less weight (i.e. grew more rapidly) and had higher tissue $N$ levels than control (unenriched) algae (Table 1)

\section{DISCUSSION}

Our studies of $\mathrm{N}$ availability, critical $\mathrm{N}$ content, and the effects of in situ $N$ enrichment allow us to integrate the results from 3 methods of assessing $N$ limitation of macroalgal growth. The first method predicts $N$ limitation during periods of low $\mathrm{N}$ availability as measured by water column concentrations. High temporal resolution is required, because some algae may have limited capacities to store $\mathrm{N}$ for growth (Fujita 1985a) and could become $\mathrm{N}$-limited between intermittent upwelling events. The second method predicts $N$ limitation when tissue $\mathrm{N}$ levels of algae from natural communities are less than a critical value established in culture experiments. The third method predicts $\mathrm{N}$ limitation when enrichment with $N$ results in increased growth.

We have assumed in this study that dissolved organic $\mathrm{N}$ is not an important $\mathrm{N}$ source for rocky intertidal macroalgae. Ulva spp. can use urea and amino acids as nitrogen sources (Nasr et al. 1968, Mohsen et al. 1974). However, in general the capacity of macroalgae to utilize organic forms of $\mathrm{N}$ is very limited (Stephens 1981). Furthermore, concentrations of both urea (Kokkinakis \& Wheeler 1988) and primary amines (measured by fluorescamine, Wheeler unpubl.) are not particularly high in the Oregon coastal waters, and we feel justified in excluding these possible $\mathrm{N}$ sources in the present discussion.

Based on water column $N$ concentrations, we would predict that Pelvetiopsis limitata growth would be Nlimited only in March and April, when inorganic $N$ levels were consistently low. To apply the critical $N$ concept to field populations of $P$. limitata, it is necessary to determine the major $N$ source for growth because the $\mathrm{N}$ source affects the critical $\mathrm{N}$ relationship (Fig. 5A). We can make a rough estimation of the relative contributions of $\mathrm{NH}_{4}^{+}$and $\mathrm{NO}_{3}^{-}$to total $\mathrm{N}$ demand by constructing a $\mathrm{N}$ budget (Table 2). In our calculations, we estimated mean exposure time at low tides by direct observation throughout the year (A. Olsen pers. comm.) and assumed that the low tides were symmetrical (resulting in an overestimation of exposure time, since all observations were made at the lowest-low tides). We further assumed that $\mathrm{NO}_{3}^{-}$ uptake is light dependent while $\mathrm{NH}_{4}^{+}$uptake is not 
Table 2. Pelvetiopsis limitata. Nitrogen budget for in situ growth at Yaquina Head, Oregon. Uptake rates were measured as a function of $\mathrm{N}$ concentration in short-term laboratory experiments and used in conjunction with ambient nutrient concentrations to calculate in situ uptake rates

\begin{tabular}{|c|c|c|c|c|c|}
\hline \multirow[t]{2}{*}{ Month } & \multirow{2}{*}{$\begin{array}{l}\text { Time } \\
\text { submersed } \\
\text { per day } \\
\text { (h) }\end{array}$} & \multicolumn{2}{|c|}{$\begin{array}{c}\text { Estimated in situ } \\
\text { uptake rate } \\
\left(\mu \mathrm{mol}[\mathrm{g} d r y w t]^{-1} h^{-1}\right)\end{array}$} & \multicolumn{2}{|c|}{$\begin{array}{l}\% \mathrm{~N} \text { required for } \\
\text { maximum growth } \\
\text { potentially } \\
\text { supplied }\end{array}$} \\
\hline & & $\mathrm{NO}_{3}^{-}$ & $\mathrm{NH}_{4}^{+}$ & $\mathrm{NO}_{3}^{-}$ & $\mathrm{NH}_{4}^{+}$ \\
\hline Jan & 9 & 1.7 & 3.7 & 26 & 113 \\
\hline Feb & 5 & 1.6 & 3.7 & 30 & 143 \\
\hline Mar & 7 & 0.8 & 3.7 & 14 & 132 \\
\hline Apr & 8 & 1.0 & 5.3 & 16 & 174 \\
\hline May & 8 & 1.7 & 5.3 & 28 & 174 \\
\hline Jun & 9 & 4.6 & 5.3 & 71 & 163 \\
\hline Jul & 11 & 2.2 & 3.7 & 28 & 96 \\
\hline Aug & 9 & 1.6 & 3.7 & 24 & 113 \\
\hline Sep & 8 & 2.0 & 3.7 & 33 & 122 \\
\hline Oct & 12 & 1.6 & 5.3 & 19 & 130 \\
\hline Nov & $9^{a}$ & 1.6 & 3.7 & 25 & 116 \\
\hline Dec & $9^{a}$ & 1.6 & 3.7 & 25 & 116 \\
\hline
\end{tabular}

(Hanisak 1983), that growth rate was constant at $4 \%$ $\mathrm{d}^{-1}$ (growth rates in outdoor cultures varied between 2 and $4 \% \mathrm{~d}^{-1}$ and in situ growth rates averaged $3.9 \%$ $\mathrm{d}^{-1}$ ), and that tissue $\mathrm{N}$ levels averaged $1.7 \%$ dry wt throughout the year (mean of all tissue $N$ values in Fig. 3; standard deviation $=0.23$ ). The budget indicates that $\mathrm{NO}_{3}^{-}$could account for 14 to $33 \%$ of the $\mathrm{N}$ demand, while $\mathrm{NH}_{4}^{+}$could potentially supply 96 to $174 \%$ of the total $N$ demand (Table 2). The uptake rates used in the calculation of the $N$ budget were measured in short-term experiments and may overestimate long-term or steady-state uptake (Probyn \& Chapman 1982), resulting in percentages of the total $N$ demand supplied by $\mathrm{NH}_{4}^{+}$in excess of $100 \%$ (Table 2). Nonetheless, it is unlikely that in situ growth is $\mathrm{N}$ limited. The in situ enrichment experiment, however, suggests that, despite high $\mathrm{N}$ concentrations present during early May, $P$. limitata growth may have been $\mathrm{N}$ limited (Table 2). The algae in the control treatment had a tissue $\mathrm{N}$ level of $1.5 \%$ dry wt while $\mathrm{N}$-enriched thalli had a tissue $N$ content of $1.9 \%$ dry wt. Since the critical $N$ level for growth in outdoor cultures was $\geq 1.5 \%$ dry $w t$, these results suggest that $P$. limitata was growing on $\mathrm{NO}_{3}^{-}$in situ.

The 3 methods for the assessment of $\mathrm{N}$ limitation used in this study (water column DIN concentrations, critical tissue $\mathrm{N}$ level, and in situ enrichment) do not yield the same conclusion for Pelvetiopsis limitata. Water column DIN concentrations indicate that $P$. limitata may be $\mathrm{N}$-limited in March and April (Fig. 2A). The critical $N$ levels obtained in outdoor culture coupled with the results of the $\mathrm{N}$ budget (i.e. that $\mathrm{NH}_{4}^{+}$ is the major $\mathrm{N}$ source in the field) indicate that this species is never likely to be $\mathrm{N}$-limited. The results of the in situ enrichment experiment indicate that $P$. limitata may be $\mathrm{N}$-limited in April and May only if $\mathrm{NO}_{3}^{-}$ is the major $\mathrm{N}$ source for growth in the field, contrary to the conclusion drawn from $\mathrm{N}$ budget analysis (Table 2).

Based on water column $N$ concentrations, Ulva rigida would also only exhibit $\mathrm{N}$ limitation in April and May. The relationships between growth and critical $N$ content depended on $\mathrm{N}$ source in outdoor culture $13.0 \%$ dry wt on $\mathrm{NH}_{4}^{+}$, $\leq 2.4 \%$ dry wt on $\mathrm{NO}_{3}^{-}$). A $\mathrm{N}$ budget was constructed to determine which $N$ source was more important in situ. We assumed that thalli were always submerged, experienced $10 \mathrm{~h}$ of light during the spring and $12 \mathrm{~h}$ during the summer, and that $\mathrm{N}$ content and grow th rate varied from $3 \%$ dry wt and $20 \% \mathrm{~d}^{-1}$ to $4 \%$ dry wt and $30 \% \mathrm{~d}^{-1}$ in the spring and summer, respectively. The budget (Table 3 ) indicates that $\mathrm{NH}_{4}^{+}$may supply most of the $\mathrm{N}$ requirements for growth despite much higher concentrations of $\mathrm{NO}_{3}^{-}$. Using the critical $\mathrm{N}$ level derived from the outdoor cultures of U. rigida on $\mathrm{NH}_{4}^{+}(3.0 \%$ dry wt), growth is just on the verge of $\mathrm{N}$ limitation most of the spring (Fig. 3).

We were unable to conduct an in situ $\mathrm{N}$ enrichment study with Ulva rigida due to excessive tissue loss. Similarly, we were unable to measure the growth rate of Ulva spp. in situ. However, our outdoor cultivation studies indicate that the growth rate of these algae can be relatively high (up to $12 \% \mathrm{~d}^{-1}$ ). Many other workers have also reported high growth rates for UIva spp. (e.g., Lapointe \& Tenore 1981, Fujita 1985a, Duke et al. 1986). Ulva and Enteromorpha spp. are capable of extremely rapid $\mathrm{N}$ uptake when $\mathrm{N}$ availability is high, and continued growth for up to $5 \mathrm{~d}$ after $\mathrm{N}$ is depleted (Fujita 1985a, O'Brien 1987). However, because $N$ pulses sometimes occur as much as $6 \mathrm{~d}$ apart at Yaquina Head, ulvoid algae may be intermittently $\mathrm{N}$ limited if growth rates are high enough to deplete stored tissue $\mathrm{N}$ and ambient $\mathrm{N}$ is too low to maintain growth rates.

When $N$ was provided only once every $5 \mathrm{~d}$ in a field experiment, ulvoids decreased in abundance while the red alga Gracilaria tikvahiae (which can grow for $14 \mathrm{~d}$ in the absence of $N_{i}$ Ryther et al. 1981, Fujita 1985a), dominated mixed beds (Fujita 1985b). Nitrogen uptake by Ulva rigida is rapid (ca $12 \mu \mathrm{mol} \mathrm{N} \mathrm{g} \mathrm{dry} \mathrm{wt}^{-1} \mathrm{~h}^{-1}$ ) even at low concentrations ( $2 \mu M$; Fujita unpubl.). Uptake at $2 \mu M N$ would provide sufficient $N$ to support growth at $16 \% \mathrm{~d}^{-1}$ of $U$. rigida containing $2.5 \%$ dry wt $N$. Very high growth rates (ca $27 \% \mathrm{~d}^{-1}$. Davis 1981) would result in greater $\mathrm{N}$ demand and possible $\mathrm{N}$ limitation. More measurements of growth rates and tissue $N$ levels in naturally occurring thalli and an in situ enrichment experiment are needed to test these possibilities. 
Table 3. Ulva rigida. Nitrogen budget for in situ growth at Yaquina Head, Oregon. Uptake rates were measured as a function of $\mathrm{N}$ concentration in short-term laboratory experiments and used in conjunction with ambient $N$ concentrations to calculate in situ uptake rates

\begin{tabular}{|c|c|c|c|c|c|c|c|}
\hline \multirow[t]{2}{*}{ Month } & \multirow[t]{2}{*}{$\begin{array}{c}\text { Hours daylight } \\
\text { per day }\end{array}$} & \multicolumn{2}{|c|}{$\begin{array}{c}\text { Mean } N \text { concentration } \\
(\mu M)\end{array}$} & \multicolumn{2}{|c|}{$\begin{array}{l}\text { Estimated uptake rate } \\
\left.(\text { umol[g dry } w t)^{-1} h^{-1}\right)\end{array}$} & \multicolumn{2}{|c|}{$\begin{array}{l}\% N \text { required for maximum } \\
\text { growth potentially supplied }\end{array}$} \\
\hline & & $\mathrm{NO}_{3}^{-}$ & $\mathrm{NH}_{4}^{+}$ & $\mathrm{NO}_{3}^{-}$ & $\mathrm{NH}_{a}^{+}$ & $\mathrm{NO}_{3}^{-}$ & $\mathrm{NH}_{4}^{+}$ \\
\hline Jan & 8 & 8.4 & 1.00 & 23.4 & 6.0 & 134 & 103 \\
\hline Feb & 8 & 8.2 & 1.07 & 22.2 & 6.0 & 127 & 103 \\
\hline Mar & 10 & 3.0 & 1.14 & 10.2 & 6.0 & 32 & 46 \\
\hline Apr & 10 & 3.4 & 2.50 & 27.6 & 32.4 & 64 & 181 \\
\hline May & 10 & 8.7 & 2.31 & 72.0 & 26.4 & 168 & 148 \\
\hline Jun & 12 & 33.2 & 2.71 & 16.8 & 24.6 & 23 & 69 \\
\hline Jul & 12 & 14.6 & 1.51 & 19.2 & 18.0 & 27 & 50 \\
\hline Aug & 12 & 19.8 & 1.24 & 18.6 & 18.0 & 26 & 50 \\
\hline Sep & 10 & 10.8 & 1.22 & 13.8 & 18.0 & 32 & 101 \\
\hline Oct & 10 & 7.1 & 3.20 & 21.0 & 12.6 & 150 & 216 \\
\hline Nov & 10 & 8.4 & 1.14 & 24.0 & 5.4 & 171 & 93 \\
\hline Dec & 8 & 8.3 & 1.00 & 23.4 & 6.0 & 134 & 103 \\
\hline
\end{tabular}

The critical $N$ concept appears to be a useful tool for diagnosing $\mathrm{N}$ limitation of Ulva rigida growth because it provides a relationship between an index of $\mathrm{N}$ status (tissue $\mathrm{N}$ content) and growth rate. Nitrogen source has a strong effect on the relationship; growth on $\mathrm{NH}_{4}^{+}$ yielded a higher critical $\mathrm{N}$ level $(3.0 \%$ dry wt) than growth on $\mathrm{NO}_{3}^{-}(\leq 2.4 \%$ dry wt). Similarly, the relationship between tissue $\mathrm{N}$ and growth of Pelvetiopsis limitata is strongly dependent upon $\mathrm{N}$ source and other culture conditions. The low $\mathrm{N}$ loadings used in the indoor cultures should have resulted in lower $\mathrm{N}$ content and low growth rates, as seen for $U$. rigida (Fig. 5B). Even though the growth rates of $P$. limitata were much lower in indoor culture, $\mathrm{N}$ content varied over a wide range $(0.6$ to $1.6 \%$ dry wt) which included $N$ contents of algae grown outdoors (Fig. 5A). This indicates that, in spite of provision of micronutrients and adequate light, some factor other than $\mathrm{N}$ availabilty limited growth of $P$. limitata indoors. The elevated growth rates obtained with $\mathrm{NH}_{4}^{+}$as the $\mathrm{N}$ source (in comparison with $\mathrm{NO}_{3}^{-}$) at equivalent tissue $\mathrm{N}$ levels suggest that it is energetically more favorable to assimilate $\mathrm{NH}_{4}^{+}$than $\mathrm{NO}_{3}^{-}$for both species (Fig. 5A, B). The critical $\mathrm{N}$ levels established in this study for $P$. limitata fall within the range of critical $\mathrm{N}$ levels established for other species; however, critical $\mathrm{N}$ levels for $U$, rigida exceed this range (Table 4).

The relationship between Pelvetiopsis limitata growth rate and influent $\mathrm{NH}_{4}^{+}$concentration indicates that $P$. limitata growth was $\mathrm{N}$-limited at influent $\mathrm{NH}_{4}^{+}$ loadings less than $4.3 \mathrm{mmol} \mathrm{d}^{-1}(20 \mu \mathrm{M})$ in outdoor culture, while growth did not saturate at the highest $\mathrm{NO}_{3}^{-}$loading tested $\left(10.8 \mathrm{mmol} \mathrm{d}^{-1} ; 50 \mu \mathrm{M}\right)$ (Fig. 4A). Growth at nominally zero $\mathrm{N}$ concentration or loading was probably supported by $\mathrm{N}$ (both DIN and DON) remaining after nutrient stripping (0 to $3 \mu M$ total DIN).

Table 4. Critical $\mathrm{N}$ levels as \% dry wt for marine macroalgae

\begin{tabular}{|lcl|}
\hline Species & $\begin{array}{c}\text { Critical N } \\
(\% \text { dry wt) }\end{array}$ & Source \\
\hline Cladophora albida & 2.1 & Gordon et al. (1981) \\
Cladophora spp. & 1.5 & Wong \& Clark (1976) \\
Codium fragile & 2.1 & Hanisak (1979) \\
Chordaria flagelliformis & 0.7 & Rosenberg et al. (1984) \\
& 1.2 & Probyn \& Chapman (1983) \\
Pelvetiopsis Limitata & & This study \\
outdoors on $\mathrm{NH}_{4}^{+}$ & $<0.9$ & This study \\
outdoors on $\mathrm{NO}_{3}^{-}$ & $\geq 1.5$ & This study \\
indoors on $\mathrm{NH}_{4}^{+}$ & Not determined & $\leq 1.2$ \\
indoors on $\mathrm{NO}_{3}^{-}$ & & This study \\
Ulva rigida & 3.0 & This study \\
outdoors on $\mathrm{NH}_{4}^{+}$ & $\leq 2.4$ & \\
outdoors on $\mathrm{NO}_{3}^{-}$ & & \\
\hline
\end{tabular}


The potential effects of organic compounds produced in the high-density nutrient stripping tanks are unknown. Indoor cultures did not grow at zero $\mathrm{N}$ loading due to the more effective nutrient stripping possible with batch cultures (Fig. 4B, D).

Growth rate in indoor culture was not saturated at the highest $\mathrm{NO}_{3}^{-}$loading $(48 \mu \mathrm{mol} \mathrm{d}-1 ; 100 \mu M)$, but was $\mathrm{N}$-limited at $\mathrm{NH}_{4}^{+}$loadings less than $15 \mu \mathrm{mol} \mathrm{d}{ }^{-1}$ ) $(30 \mu \mathrm{M})$, (Fig. 4B). Growth of Ulva rigida in outdoor culture appeared to be $\mathrm{N}$-limited at influent $\mathrm{NO}_{3}^{-}$loadings less than $6.48 \mathrm{mmol} \mathrm{d} \mathrm{d}^{-1}(30 \mu \mathrm{M})$, but was not saturated with $\mathrm{NH}_{4}^{+}$(Fig. $4 \mathrm{C}$ ). U. rigida growth appears to be $\mathrm{N}$-limited in indoor culture at influent $\mathrm{NH}_{4}^{+}$loadings less than $25 \mu \mathrm{mol} \mathrm{d} \mathrm{d}^{-1}(20 \mu \mathrm{M})$, but growth was not saturated at any of the $\mathrm{NO}_{3}^{-}$loadings tested (Fig. 4D). These relationships cannot be used to predict $\mathrm{N}$-limited growth in nature because of the strong dependence of growth rate on water flow rate and biomass (e.g., Lapointe \& Ryther 1979, Fujita \& Goldman 1985). At higher flow rates, perhaps more characteristic of the natural habitat, growth saturation would probably occur at much lower $\mathrm{N}$ concentrations than those indicated in the present study $(>20 \mu M)$ due to the increased flux of $N$ to the algae (Fujita \& Goldman 1985). In addition, the relationships shown in Fig. 4 apply only under relatively steady-state conditions of flow rate, $\mathrm{N}$ concentration, and biomass level; these conditions probably seldom occur in nature.

In conclusion, we have shown that $\mathrm{N}$ availability based on water column $N$ concentrations is a poor indicator of $\mathrm{N}$ limitation because $\mathrm{N}$ storage by macroalgae introduces time lags between low water column $\mathrm{N}$ concentrations and the onset of $\mathrm{N}$-limited growth. Critical tissue $\mathrm{N}$ levels for Ulva rigida are different for growth on $\mathrm{NH}_{4}^{+}$and $\mathrm{NO}_{3}^{-}$, but can be used as an index of the $\mathrm{N}$ status if the identity of the major $\mathrm{N}$ source is known. A greater range of tissue $N$ levels and growth rates attained in outdoor culture (possibly by using lower flow rates) is needed for the establishment of more definitive critical $N$ levels for $U$. rigida and Pelvetiopsis limitata. The critical $N$ content for $U$. rigida was found to be $\leq 2.4 \%$ dry wt for growth on $\mathrm{NO}_{3}^{-}$and $3.0 \%$ dry wt for growth on $\mathrm{NH}_{4}^{+}$in this study. The critical $N$ levels for $P$. limitata growth in outdoor culture on $\mathrm{NH}_{4}^{+}$and $\mathrm{NO}_{3}^{-}$are $<0.9$ and $\geq 1.5 \%$ dry wt, respectively. Nitrogen budgets constructed for P. limitata and $U$. rigida indicate that the major $\mathrm{N}$ source for growth is $\mathrm{NH}_{4}^{+}$despite the greater abundance of $\mathrm{NO}_{3}^{-}$at Yaquina Head. Therefore, the critical $\mathrm{N}$ level for predicting $\mathrm{N}$ limitation in the field was based on the relationship between tissue $\mathrm{N}$ content and growth on $\mathrm{NH}_{4}^{+}$in culture. The critical $N$ levels for $P$. limitata growth on $\mathrm{NH}_{4}^{+}$in outdoor culture $(<0.9 \%$ dry wt) is not consistent with the results of a field enrichment experiment, in which thalli with tissue $\mathrm{N}$ content of $1.5 \%$ dry wt appeared to be $\mathrm{N}$-limited. The critical $\mathrm{N}$ level for $U$. rigida growth on $\mathrm{NH}_{4}^{+}$in outdoor culture $(3.0 \%$ dry wt) indicates that growth was at times $\mathrm{N}$-limited in the spring. Nitrogen budgets that assess the relative contributions of $\mathrm{NH}_{4}^{+}$and $\mathrm{NO}_{3}^{-}$to total $\mathrm{N}$ demand must be used in conjunction with critical $N$ levels for both $N$ species to assess $N$ limitation for algal species that exhibit relationships between growth and $N$ content that depend on the $\mathrm{N}$ source.

Acknowledgements. This work was supported by NSF grant OCE-8501365 to P. A. Wheeler and R. M. Fujita. We gratefully acknowledge the technical assistance of M. Burger, M. Gosla, K. Keenan, and P. J. Koontz.

\section{LITERATURE CITED}

Chapman, A. R. O., Craigie, J. S. (1977). Seasonal growth in Laminaria longicruris: relations with dissolved inorganic nutrients and internal reserves of nitrogen. Mar. Biol. 40: $197-205$

Davis, M. (1981). Production dynamics of sediment-associated algae in two Oregon estuaries. Ph. D. thesis, Oregon State University

Davison, I. R., Andrews, M. Stewart, W. D. P. (1984). Regulation of growth in Laminaria digitata: use of in-vivo nitrate reductase activities as an indicator of nitrogen limitation in field populations of Laminaria spp. Mar. Biol. 84: 207-217

Droop, M. R. (1974). The nutrient status of algal cells in continuous culture. J. mar. biol. Ass. U.K. 54:825-855

Duke, C. S., Lapointe, B. E., Ramus, J. (1986). Effects of light on growth, RuBPCase activity and chemical composition of Ulva species (Chlorophyta). J. Phycol. 22: 362-370

Eppley, R. W., Strickland, J. D. H. (1968). Kinetics of marine phytoplankton growth. In: Droop, M. R., Wood, E. J. F. (eds.) Advances in Microbiology of the Sea. Vol. 1. London, Academic Press, p. 23-62

Fujita, R. M. (1985a). The role of nitrogen status in regulating transient ammonium uptake and nitrogen storage by macroalgae. J. exp. mar. Biol. Ecol. 92: 283-301

Fujita, R. M. (1985b). The role of nitrogen supply variability in regulating nitrogen uptake by macroalgae and in structuring a macroalgal community. Ph. D. thesis, Boston University

Fujita, R. M., Goldman, J. C. (1985). Nutrient flux and growth of the red alga Gracilaria tikvahiae McLachlan (Rhodophyta). Botanica mar. 28: 265-268

Gagne, J. A., Mann, K. H., Chapman, A. R. O. (1982). Seasonal pattern of growth and storage in Laminaria longicruris in relation to differing patterns of availability of nitrogen in the water. Mar. Biol. 69: 91-101

Gerard, V. A. (1982). Growth and utilization of internal nitrogen reserves by the giant kelp Macrocystis pyrifera in a low-nitrogen environment. Mar. Biol. 66: 27-35

Gordon, D. M., Birch, P. B., McComb, A. J. (1981). Effects of inorganic phosphorus and nitrogen on the growth of an estuarine Cladophora in culture. Botanica mar. 24: 95-106

Grasshoff, K., Ehrhardt, Kremling, K. (1983). Methods of seawater analysis. Verlag Chemie, Weinheim

Guillard, R. R. L. (1975). Culture of phytoplankton for feeding marine invertebrates. In: Smith, W L. Chanley, M. H. (eds.) Culture of marine invertebrates. Plenum, New York p. $26-60$ 
Hanisak, M. D. (1979). Nitrogen limitation of Codium fragile ssp. tomentosoides as determined by tissue analysis. Mar Biol. 50: 333-337

Hanisak, M. D. (1983). The nitrogen relationships of marine macroalgae. In: Carpenter, E. J., Capone, D. G. (eds.) Nitrogen in the marine environment. Academic Press, New York, p. 699-730

Harlin, M. M., Thorne-Miller, B. (1981). Nutrient enrichment of seagrass beds in a Rhode Island coastal lagoon. Mar. Biol. 65: 221-229

Kokkinakis, S. A., Wheeler, P. A. (1988). Uptake of ammonium and urea in the northeast Pacific: comparison between netplankton and nanoplankton. Mar Ecol. Prog. Ser. 43 113-124

Lapointe, B. E. (1985). Strategies for pulsed nutrient supply to Gracilaria cultures in the Florida keys: interactions between concentration and frequency of pulses. J. exp. mar. Biol. Ecol. 93: 211-222

Lapointe, B. E., Ryther, J. H. (1979). The effects of nitrogen and seawater flow rate on the growth and biochemical composition of Gracilaria folifera var. angustissima in mass outdoor cultures. Botanica mar. 22: 529-537

Lapointe, B. E, Tenore, K. R. (1981). Experimental outdoor studies with Ulva fasciata Delile. I. Interactions of light and nitrogen on nutrient uptake, growth, and biochemical composition. J. exp. mar Biol. Ecol. 53: 135-152

Mohsen, A. F., Khaeafa, A. F., Metwalli, A. (1974). Effect of different nitrogen sources on growth, reproduction, amino acid, fat and sugar contents in Ulva fasciata Delile. Botanica mar. 17: 218-222

Nasr, A. H., Bekheet, I. A., Ibrahim, R. K. (1968). The effects of different nitrogen and carbon sources on amino acid synthesis in Ulva, Dictyota, and Pterocladia. Hydrobiologia $31: 7-16$

NOAA (1985). Sea surface thermal analyses. Issued every 3 days by the Northwest Ocean Service Center, 7600 Sand Point Way NE, Bin CI5700, Seattle, Washington, U.S. Department of Commerce, National Oceanic and Atmospheric Administration

O'Brien, M. C. (1987). Nitrogen and phosphorus uptake by Enteromorpha prolifera (Mull.) J. Ag. M. S. thesis, Oregon State University

Oakes, B. R., Murray, S. N. (1983). Photosynthesis, dark respi-

This article was presented by Professor K. Banse, Seattle, Washington, USA ration and desiccation resistance of the intertidal seaweeds Hesperophycus harveyanus and Pelvetia fastigiata f. gracilis. J. Phycol. 19: $371-380$

Probyn, T. A., Chapman, A. R. O. (1982). Nitrogen uptake characteristics of Chordaria flagelliformis (Phaeophyta) in batch mode and continuous mode experiments. Mar. Biol. 71. 129-133

Probyn, T. A., Chapman, A. R. O. (1983). Summer growth of Chordaria flagelliformis (O. F. Muell.) C. Ag.: physiological strategies in a nutrient stressed environment. J. exp. mar. Biol. Ecol, 73: 243-271

Rosenberg, G., Probyn, T A., Mann, K. H. (1984). Nutrient uptake and growth kinetics in brown seaweeds: response to continuous and single additions of ammonium. J. exp mar. Biol. Ecol. 80: 125-146

Rosenberg, G., Ramus, J. (1982). Ecological growth strategies in the seaweeds Gracilaria foliffera (Rhodophyceae) and Ulva sp. (Chlorophyceae): soluble nitrogen and reserve carbohydrates. Mar. Biol. 66: 251-259

Ryther, J. H., Corwin, N., De Busk, I. A., Williams, L. D (1981). Nitrogen uptake and storage by the red alga Gracilaria tikvahiae (McLachlan, 1979). Aquaculture 26 $107-115$

Small, L. F., Menzies, D. W. (1981). Patterns of primary productivity and biomass in a coastal upwelling region. Deep Sea Res. 28: 123-149

Smith, P. F., (1962). Mineral analysis of plant tissue. Ann. Rev. Plant Physiol. 13: 81-108

Stefánsson, U., Richards, F. A. (1964). Distributions of dissolved oxygen, density, and nutrients off the Washington and Oregon coasts. Deep Sea Res. 11: 355-380

Stephens, G. C. (1981). The trophic role of dissolved organic material. In: Longhurst, A. R. (ed.) Analysis of marine ecosystems. Academic Press, New York, p. 271-292

Ulrich, A. (1952). Physiological basis for assessing the nutritional requirements of plants. Ann. Rev. Plant Physiol. 3: 207-228

Wong, S. L., Clark, B. (1976). Field determination of the critical nutrient concentrations for Cladophora in streams. J. Fish. Res. Bd Can. 33: 85-92

Zimmerman, R. C., Kremer, J. N. (1984). Episodic nutrient supply to a kelp forest ecosystem in Southern California. J. mar. Res. 42: 591-604

Revised version accepted: February 17, 1989 